Cardiology (ESC) [2013 ESC/ESH Guidelines for the management of arterial hypertension] Russ J. Cardiol 2014, 1 (105): 7-94

3. The Task Force for the management of arterial hypertension of the European Society of Cardiology and the European. [2018 ESC/ESH Guidelines for the management of arterial hypertension] J. of Hypertension. 37(1):226, January 2019; 1956-1994

4. Танашян М. М., Домашенко М. А., Раскуражев А. А., Аспиринорезистентность: клинические и молекулярно-генетические методики. журн. Анналы неврологии. ФГБНУ. «Научній центр неврологии»- М., 2016 - Том 10 № 1. ISSN: 2409-2533

5. Чекман I. С., та ін. Фармакологія: підруч. - К. : Вища шк., [2001] $598 \mathrm{c}$.

6. Fan L., Cao J., Liu L., et al. Frequency, risk factors, prognosis, and genetic polymorphism of cyclooxygenase-1 gene for aspirsn resistance in elderly Chinese patients with cardiovascular disease / Gerontology 2013; 59: 122-131.

7. Michelson F.D., et al. Resistance to antiplatelet drug. Eur. Haert. J. 2006; 8 (suppl.G): 53-58.

DOI https://doi.org/10.30525/978-9934-588-81-5-1.53

\title{
ПІЛОНІДАЛЬНА ХВОРОБА У ДІТЕЙ. АНАЛІЗ МЕТОДІВ ОПЕРАТИВНОГО ЛІКУВАННЯ
}

\author{
Шавлюк Р. В. \\ аспірант кафедри дитячої хірургї \\ Вінницький національний медичний університет імені М. І. Пирогова \\ м. Вінниця, Украӥна
}

Актуальність теми. Пілонідальна хвороба крижово-куприкової ділянки - збірне поняття патології, під якою мають на увазі комплекс патологічних проявів, які виникають і реалізуються під впливом несприятливих факторів зовнішнього середовища остаточним морфологічним субстратом якого є формування пілонідальної кісти $[1,2]$. Однак на нашу думку пілонідальна хвороба - гостре, хронічне або рецидивуюче запалення епітеліальних куприкових ходів у товщі м'яких тканин (підшкірно-жировій клітковині) в ділянці міжсідничної складки крижово-куприкової області. Ї̈̈ поширення серед дорослого населення досить чітко визначена, але так як ії дебют найбільш часто виникає у дитячому віці (із 15-16 років), це потребує деталізації отри- 
маних даних. I хоч дана патологія вперше була описана іще у 1847 році, але досі не отримала єдиних загальноприйнятих рекомендацій щодо методів її хірургічного лікування.

Мета роботи: проаналізувати результати хірургічного лікування пілонідальної хвороби у дітей.

Матеріали і методи: у дослідження включено 75 пацієнтів із діагнозом «пілонідальна хвороба», які проходили стаціонарне лікування в клініці дитячої хірургії Вінницького національного медичного університету ім. М. I. Пирогова 32017 по 2020 pp. Середній вік пацієнтів складав $15 \pm 3$ роки. Хлопчиків було 40, дівчаток - 35. Серед них 53 дітям виконано невідкладне оперативне втручання (розкриття та дренування пілонідального абсцесу), 22 - радикальне оперативне втручання, 3 яких 16 - модифіковане оперативне втручання за cleft-lift методикою.

Результати дослідження. Відповідно до результатів дослідження показовим $є$ той факт того, що кількість дівчаток та хлопчиків співвідноситься як 1:0,875. Це свідчить про збільшення частоти виникнення пілонідальної хвороби серед осіб жіночої статі за останні роки. Кількість поворотних звернень складала 23, що відповідає загальній кількості рецидивів $23,5 \%$. Також проаналізовано результати радикального лікування пілонідальної хвороби у дітей за стандартною методикою із формуванням серединної рани та серединного рубця у подальшому (перша група) та за модифікованою cleft-lift методикою на основі іiі математичного моделювання (друга група) [3]. Кількість кість випадків рецидиву захворювання у першій групі із 6 чоловік склав 3, що відповідає 50\%. Також у одного пацієнта $(16,7 \%)$ відмічався ускладнений післяопераційний період за рахунок розходження післяопераційної рани. У осіб другої групи (16 чоловік) кількість рецидивів захворювання склала 1 випадок $(6,3 \%)$, та у 1 пацієнта $(6,3 \%)$ відмічалося післяопераційне ускладнення у вигляді виникнення ранньої неспроможності післяопераційних швів, що призвело до розходження країв рани.

Висновки:

1. Висока кількість рецидивів пілонідальної хвороби у дітей після оперативних втручань змушує продовжувати пошук оптимальних методів корекції даної патології;

2. За останній роки збільшилась кількість випадків пілонідальної хвороби у дівчаток, що змушує переглянути дані щодо епідеміології даного захворювання;

3. Виконання модифікованого оперативного втручання по cleft-lift методиці із його математичним моделюванням дозволяє зменшити частоту післяопераційних ускладнень та рецидивів пілонідальної хвороби у дітей. 


\title{
Література:
}

1. Цема Є.В. Порівняльна оцінка ефективності методів радикального хірургічного лікування гострої пілонідальної хвороби. Український журнал малоінвазивної та ендоскопічної хірургї. - 2013. - Т. 17, № 3. - C. 22-29.

2. Thompson M.R. Pilonidal sinus disease. Anorectal and colonic diseases. A practical guide to their management / M.R.Thompson, A.Senapati, R.B. Kitchen editors: Jean-Claude R. Givel, Neil Mortensen, Bruno Roche. 3rd ed. (Springer). - 2010. - P. 373-386.

3. Шавлюк Р.В., Конопліцький В.С., Паламарчук І.П. Модельне обгрунтування просторових параметрів хірургічного доступу при мініінвазивному оперативному лікуванні пілонідальної хвороби у дітей. Хірургія дитячого віку. - 2020. - Т. 66, № 1. С. 10-20.

DOI https://doi.org/10.30525/978-9934-588-81-5-1.54

\section{PROBLEM OF CHOICE: ELECTRONIC CIGARETTES IN THE MEDICAL ENVIRONMENT}

\author{
Yashkina T. O. \\ Assistant at the Department of Family Medicine \\ of the Faculty of Postgraduate Education \\ State Institution "Dnipropetrovsk Medical Academy \\ of the Ministry of Health of Ukraine" \\ Dnipro, Ukraine
}

Introduction. At the present stage of development of society, medical practice pays considerable attention to the impact of active and passive smoking on different groups of the population, adults $[2,4]$ and children [3]. Despite the programs to counter the spread of tobacco smoking (MPOWER), adopted in more than 150 countries around the world, the tobacco industry is successfully increasing the number of consumers [1]. The emergence and active spread of new forms of tobacco smoking is attracting an increasing number of people, especially among young people. Future medical workers are no exception.

Materials and methods. An anonymous survey was conducted using the questionnaire of the Global Adult Tobacco Survey (GATS) for Ukraine, modified and adapted by us in accordance with our goal.

The anonymous survey was attended by 171 people (medical students and interns) aged 18 to 30 years. 